\title{
Nonspecific Interstitial Pneumonia, Alveolar Proteinosis, and Abnormal Proprotein Trafficking Resulting from a Spontaneous Mutation in the Surfactant Protein C Gene
}

\author{
PAUL A. STEVENS, ANDREA PETTENAZZO, FRANK BRASCH, SURAFEL MULUGETA, \\ ALDO BARITUSSIO, MATTHIAS OCHS, LAKE MORRISON, SCOTT J. RUSSO, AND \\ MICHAEL F. BEERS
}

Pulmonary and Critical Care Division [S.M., L.M., S.J.R., M.F.B.], Department of Medicine, University of Pennsylvania School of Medicine, Philadelphia, Pennsylvania 19104, Clinic of Neonatology [P.A.S.], University Children's Hospital Charité, 10098, Berlin, D-10098 Germany, Departments of Medical and Surgical Sciences and Pediatrics [A.P., A.B.], University of Padua, 35128 Padua, 35122, Italy, Institute of Pathology [F.B.], University Hospital “Bergmannsheil," D-44789 Bochum, Germany, Division of Electron Microscopy [F.B., M.O.], Department of Anatomy, University of Göttingen, 37075 Göttingen, Germany

\section{ABSTRACT}

Human surfactant protein C (hSP-C $\left.{ }^{1-197}\right)$ is synthesized as a 197 amino acid proprotein and cleaved to a mature $3.7 \mathrm{kD}$ form. Although interstitial lung disease in patients with mutations of the hSP-C gene is becoming increasingly recognized, the mechanisms linking molecular events with clinical pathogenesis are not fully defined. We describe a full-term infant with respiratory insufficiency associated with a spontaneous heterozygous mutation resulting in a substitution of lysine for glutamic acid at position $66(=\mathrm{E} 66 \mathrm{~K})$ of the proximal hSP-C COOH flanking propeptide. Lung histology and biochemical studies of the index patient (hSP-C $\mathrm{C}^{\mathrm{E} 66 \mathrm{~K}}$ ) revealed nonspecific interstitial pneumonia, increased alveolar total phospholipid lacking phosphatidylglycerol, and increased surfactant protein A. Localization of proSP-C from lung sections prepared from this patient using immunofluorescence and immunogold electron microscopy revealed abnormal proSP-C staining in endosomal-like vesicles of type II cells distinct from SP-B. To evaluate the effect of the E66K substitution on intracellular trafficking of proSP-C, fusion proteins consisting of enhanced green fluorescent protein (EGFP) and hSP$\mathrm{C}^{1-197}$ (wild type) or mutant $\mathrm{hSP}-\mathrm{C}^{\mathrm{E} 66 \mathrm{~K}}$ were generated and transfected into A549 cells. EGFP/hSP-C ${ }^{1-197}$ was expressed within CD-63-positive, EEA-1-negative vesicles, whereas
EGFP/hSP-C ${ }^{\text {E66K }}$ localized to EEA-1 positive vesicles. The E66K substitution is representative of a new class of SP-C mutation associated with interstitial lung disease that is diverted from the normal biosynthetic pathway. We propose that, similar to other storage disorders, lung injury results from induction of a toxic gain of function induced by the mutant product that is subject to genetic modifiers and environmental influences. (Pediatr Res 57: 89-98, 2005)

BAL, bronchoalveolar lavage

\section{Abbreviations}

BPD, bronchopulmonary dysplasia

EEA-1, early endosome antigen-1

EGFP, enhanced green fluorescent protein

EM, electron microscopy

ER, endoplasmic reticulum

GM-CSF, granulocyte macrophage colony-stimulating factor

ILD, interstitial lung disease

PAP, pulmonary alveolar proteinosis

PC, phosphatidylcholine

PG, phosphatidylglycerol

SP-A, SP-B, SP-C, SP-D, pulmonary surfactant proteins A, B, C, D
Pulmonary surfactant is a biochemically heterogeneous surface-active mixture of phospholipids and proteins secreted into

Received May 17, 2004; accepted July 12, 2004

Correspondence: Michael F. Beers, M.D., Pulmonary and Critical Care Division, University of Pennsylvania School of Medicine, 807 BRB II/III Building, 421 Curie Blvd., Philadelphia, PA 19104-6160; e-mail: mfbeers@mail.med.upenn.edu

Supported by National Institutes of Health grants HL-19737 (M.F.B.), HL 076064 (M.F.B.), and P50-HL56401 (M.F.B.) and German Research DFG Ste 459/4-4 (P.A.S.)

P.A.S. and A.P. contributed equally to this work.

DOI: 10.1203/01.PDR.0000147567.02473.5A the alveolar space by type II epithelial cells (1). Formation of the surfactant film at the air-liquid interface assures alveolar stability by reducing surface tension along the epithelial lining. It is now well accepted that dysfunction of the surfactant system plays an important role in the development or progression of both congenital and acquired lung diseases (1). Respiratory distress syndrome of the premature newborn due to a relative surfactant deficiency from either genetic or developmental regulatory disruption of the pulmonary surfactant pro- 
duction is the best-known clinical manifestation. In adults, abnormalities in surfactant component expression, metabolism, or functional inactivation have all been observed, most frequently in the context of acute lung injury (e.g. acute respiratory distress syndrome) (2). However, absolute and functional surfactant defects have been reported in other acute and subacute lung injuries including systemic sepsis, asthma, and bleomycin lung toxicity (3-5). In addition, disorders of surfactant homeostasis that result in an overabundance of alveolar surfactant material (PAP) have been associated with a variety of specific clinical entities including endogenous anti-GM-CSF antibodies (primary PAP), myeloproliferative disease, inorganic dusts, or select infectious agents such as Pneumocystis carinii (6).

Analysis of surfactant has identified four unique proteins, designated SP-A, -B, -C, and -D (reviewed in refs. 7 and 8). The hydrophilic proteins, SP-A and SP-D, are members of the collectin family of C-type lectins that include a number of molecules with known host-defense functions (7). The hydrophobic surfactant proteins, SP-B and SP-C, augment adsorption, spreading, and surface tension properties of phospholipid films (8). Surfactant protein $C$ is synthesized as a proprotein of $M_{r} 21,000$ that undergoes integral membrane association and posttranslational removal of $\mathrm{NH}_{2}$ and $\mathrm{COOH}$ propeptides to yield a biophysically active form (9). The posttranslational processing of a protein integrally associated with intracellular membranes before exocytosis of the membrane anchor represents a novel mechanism in mammals for the production of a secreted protein (10-13).

Generation of an SP-C null mouse has been reported (14). The phenotype of the knockout is viable with apparently normal lung function at early ages most likely due to redundancy in biophysical activity afforded by the presence of a second hydrophobic surfactant protein, SP-B. However, when backcrossed onto a different strain, SP-C knockout mice develop lung inflammation and parenchymal remodeling in adulthood suggesting genetic background may be a modifier of an SP-C deficient state (15).

Recently, there have been two full-length reports of two different mutations in the human SP-C gene associated with the production of abnormal forms of proSP-C, an absence of mature SP-C, and chronic interstitial pneumonias presenting as nonspecific interstitial pneumonia (NSIP) in affected children and usual interstitial pneumonia (UIP) in surviving adults $(16,17)$. In both circumstances, the mutation mapped to the distal portion of the $\mathrm{COOH}$ flanking propeptide and was expressed in a heterozygous fashion. This region of proSP-C $\left(\mathrm{F}^{94}-\mathrm{I}^{197}\right)$ has recently been linked with several unrelated proteins all containing a novel sequence domain termed Bri (BRICHOS) found in degenerative and proliferative disorders in other organ systems including Bri3, associated with chronic neurodegenerative dementia in British and Danish kindreds, and CA11 found in chondrosarcomas (18).

We have shown that expression of one of these BRICHOS SP-C mutations ( $\Delta$ Exon4) in epithelial cells in vitro yields to the formation of intracellular protein aggregates and diversion of both wild-type and mutant forms to a novel intracellular compartment, the aggresome (19). These findings, along with recent work showing that expression of the SP-C $\mathrm{C}^{\Delta \text { Exon4 }}$ mutation in transgenic mice disrupts lung morphogenesis (20), suggest that lung injury from expression of proSP-C proteins containing mutations in the BRICHOS domain of the propeptide is due to both a toxic gain of function from a cellular response to an aberrant, aggregating integral membrane protein as well as a dominant negative affect that down-regulates alveolar SP-C content.

In this report, we characterize the phenotype of a patient with a spontaneous mutation in a region in proSP-C spatially distinct from the aforementioned BRICHOS mutations. The heterozygous missense substitution of lysine for glutamic acid at position 66 of the proximal $\mathrm{COOH}$ flanking propeptide (hSP-C ${ }^{\mathrm{E} 66 \mathrm{~K}}$ ) was associated not only with the presence of interstitial lung disease (NSIP) in the affected patient, but also with pulmonary alveolar proteinosis. Furthermore, in vitro evaluation of trafficking of this abnormal proSP-C isoform demonstrates that this mutant was targeted abnormally to early endosomal compartments that radically differ from the pattern observed for previously reported SP-C mutations. Taken together, in vitro data coupled with the clinical findings suggest that this mutant form of SP-C protein hSP-C ${ }^{\mathrm{E} 66 \mathrm{~K}}$ represents a new class of mutant proSPC forms that accumulate outside the normal biosynthetic pathway and are capable is inducing cell damage thus proving to be equally or even more harmful than a total absence of SP-C expression.

\section{METHODS}

\section{Index Patient Summary}

The index patient is a full-term male product of nonconsanguineous parents (40 wk gestation). The pregnancy and delivery were uneventful with a recorded birth weight of $3900 \mathrm{~g}$. The infant exhibited no immediate perinatal problems and was discharged to home on hospital d 4. On the d 13 of life he was admitted to a local hospital with tachypnea, cyanosis, and hypoxemia.

Initial workup up of metabolic/infectious/immunologic etiologies was negative and on hospital d 3 the patient was transferred to a university hospital level-3 pediatric intensive care unit. Chest $\mathrm{x}$-rays showed a persistence of diffuse bilateral pulmonary infiltrates in the lungs. The infant underwent BAL with a $3.5-\mathrm{mm}$ flexible bronchoscope in the main bronchi in which approximately $2 \mathrm{~mL} / \mathrm{kg}$ of saline were introduced and immediately withdrawn three times. Typical recovery was approximately $80 \%$ of the instilled volume. Analysis of this BAL and two additional samples, collected at 2-wk intervals, revealed increased cellularity containing foamy-appearing mononuclear cells but was persistently negative for bacterial or viral pathogens.

At $5 \mathrm{wk}$ of age, ultrasound demonstrated the presence of pyloric hypertrophy with stenosis and corrective surgery was performed. The patient remained $\mathrm{O}_{2}$ dependent and an open lung biopsy was performed at the age of 2 mo that revealed the presence of NSIP (Fig. 1). The baby was eventually discharged to home requiring both mild ventilatory support (after tracheotomy) and supplemental $\mathrm{O}_{2}$.

Analysis of patient pathologic material and DNA was approved by Institutional Review Boards at the University of Pennsylvania, University of Padua, Italy, and Institute of Pathology, Bochum Germany.

Surfactant protein antisera. Monospecific polyclonal antibodies against human SP-A and SP-B were produced for use in both immunoblotting and ELISA analysis. Antiserum against SP-A was made by injection of purified surfactant SP-A obtained from lavage of a patient with alveolar proteinosis. $\mathrm{SP}-\mathrm{A}$, triple purified by butanol precipitation and extraction with $5 \mathrm{mM}$ Tris $\mathrm{HCl}$, chromatography on a column of mannose-agarose, and by two-dimension PAGE was mixed with Freund's complete adjuvant and administered subcutaneously to rabbits. The antiserum, obtained after three boosting injections of SP-A in incomplete Freund's adjuvant, does not react against SP-D. 

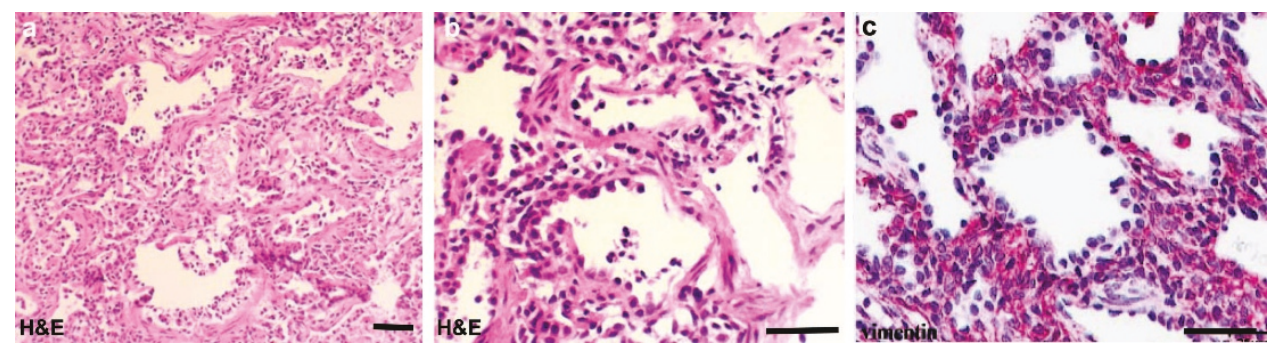

Figure 1. Photomicrographs of lung tissue from index patient. $(a, b)$ Low and higher power views of hematoxylin and eosin-stained section of open lung biopsy specimen obtained at 2 mo of age demonstrating a marked thickening of alveolar septa due to spindle-shaped cells, a mild interstitial chronic inflammation, and a hyperplasia of type II pneumocytes (NSIP). (c) Immunostaining (red staining) for vimentin indicated that thickening of alveolar septa was mainly due to mesenchymal cells. Bar $=25 \mu \mathrm{m}$.

Polyclonal antiserum against SP-B was made in an identical fashion using SP-B purified from human PAP material surfactant using Sephadex LH-60 (Amersham Biosciences, Little Chalfont, Buckinghamshire, UK) eluted with choloform:methanol:0.1 N HCl (47.5:47.5:5). The antiserum, obtained after initial injection in Freund's adjuvant and three booster injections of SP-B in incomplete Freund's adjuvant, recognizes SP-B but not SP-C.

For immunocytochemical studies, a previously described monospecific polyclonal SP-B antiserum was used (21). Monospecific polyclonal antiserum against mature human SP-C was kindly provided by Altana Pharmaceuticals, Inc., Konstanz, Germany, and has been previously characterized $(22,23)$. Polyclonal anti SP-D was obtained commercially from Chemicon, Inc., Temecula, CA. Monospecific polyclonal proSP-C antisera against $\mathrm{NH}_{2}$ terminus and $\mathrm{COOH}$ terminal propeptide domains were produced from synthetic peptide antigens and have been previously characterized (10). Each antiserum recognizes human proSP-C $\mathrm{C}_{21}$ but does not recognize mature SP-C.

Marker antisera. Anti-CD63 antiserum was purchased from Immunotech, Inc. (Marseille Cedex, France). A MAb against EEA-1 was purchased from BD Transduction Laboratories, Inc. (San Diego, CA). Anti-ubiquitin MAb was purchased from Chemicon, Inc. Texas Red (TR)-conjugated monoclonal and polyclonal antibodies were obtained from Jackson Immunoresearch Laboratories, Inc. (West Grove, PA).

PEGFP-C $\mathrm{C}_{1}$ plasmid was purchased from Clontech, Inc. (Palo Alto, CA).

\section{Preparation and Analysis of DNA}

Patient and parental genomic DNA was purified from whole blood using a commercially available kit (Pure Gene, Gentra Systems, Minneapolis, MN).

Three amplicons corresponding to the numbering in the published sequence of SP-C (24-26) spanning exon 1 (genomic positions 596-662), exons 2 to 3 (genomic positions 1366-1994), and exons 4 to 5 (genomic positions $2228-$ 2851) were amplified by PCR using the following primer sets: exon 1: 223-753: forward: 5' ACC CTT GGC CAC CTG AAA GTT C 3'; reverse: 5' AAG GAA ACA GGC CAG GGA GGA TAG 3'; exons 2 and 3: 1294-2078: forward: 5'AGC TTG TAT AGG GAG AAG AG 3'; reverse: 5' GGA TGT GGA TGA AGT GGC 3'; exons 4 and 5: 2147-2891: forward: 5' TAG AGG GAG GTG GCT AAG 3'; reverse: 5' AGC GCT CCT CCG CTG CTG ATC 3'. PCR reactions containing $1 \mu \mathrm{g}$ genomic DNA per $100 \mu \mathrm{L}$ and $0.5 \mu \mathrm{M}$ forward and reverse reaction primers, $200 \mu \mathrm{M}$ dNTP mixture, and $0.5 \mu \mathrm{L}$ of Taq polymerase ( 5 units $/ \mu \mathrm{L}$ ) were performed under the following conditions: denaturation at $95^{\circ} \mathrm{C}$ for $5 \mathrm{~min}$ followed by 30 cycles of denaturation at $95^{\circ} \mathrm{C}$ for $40 \mathrm{~s}$, annealing $60^{\circ} \mathrm{C}$ for $40 \mathrm{~s}$, and elongation at $72^{\circ} \mathrm{C}$ for $90 \mathrm{~s}$.

Purified amplicons were subjected to automated sequencing in both directions by the Core Sequencing Facility at the University of Pennsylvania and compared with the published sequences (24-26).

\section{Analysis of BAL}

Biochemical analysis of BAL. Protein concentration was determined by the method of Polacheck et al. (27). After organic extraction, total phospholipid content was measured by the method of Bartlett (28). The phospholipid composition of extracted lipids from BAL was determined by two-dimensional thin-layer chromatography according to Poorthuis et al. (29) and subsequent densitometry with a GS 700 Imaging Densitometer, (Bio-Rad, Huntingdon
Station, NY). The fatty acid profile of PC was determined as follows: after preparative two-dimensional thin-layer chromatography, PC eluted from the silica was transmethylated and fatty acids were analyzed by gas chromatography using a PerkinElmer 8320 gas chromatograph (PerkinElmer Instruments, Norwalk, CT), equipped with a $30-\mathrm{m}$ capillary column $(0.32 \mathrm{~mm}$ internal diameter, Omegawax 320, Supelco Inc., Bellefonte, PA).

To measure SP-A, an antigen competition ELISA (range of detection 0-25 $\mathrm{ng}$ ) was performed on BAL as previously published (30). The lower limit of detection of SP-A ELISA was $2.5 \mathrm{ng}$.

PAGE and immunoblotting of surfactant proteins. Aliquots of BAL were centrifuged at $150 \times g$ for $10 \mathrm{~min}$ and the resulting supernatant was centrifuged at $100,000 \times g$ for $45 \mathrm{~min}$. The pellet (purified surfactant) was solubilized, reduced, and fractionated by electrophoresis on a $10 \%$ polyacrylamide gel (31). Immunoblotting of separated proteins was done using successive incubations with primary antisera (1:5000) for $1 \mathrm{~h}$ and with horseradish peroxidase-conjugated secondary antibodies for $1 \mathrm{~h}$. Bands were visualized by enhanced chemiluminescence.

For analysis of SP-D, the $100,000 \mathrm{~g}$ supernatant was run through a $1-\mathrm{mL}$ column of mannose-Sepharose $4 \mathrm{~B}$ in the presence of $2 \mathrm{mM}$ calcium and captured SP-D eluted with $2 \mathrm{mM}$ EDTA, concentrated on a Centricon 10 concentrator (Amicon, Beverly, MA) and subjected to PAGE and immunoblotting as reported above.

\section{Morphologic Analyses}

Immunofluorescence. Immunochemical staining of immersion-fixed and paraffin- embedded lung biopsy material was performed as previously published (32,33). Fluorescence images of air-dried and Mowiol-mounted slides were viewed on an Olympus I-70 inverted fluorescence microscope with filter packages High Q FITC for EGFP (excitation at $480 \mathrm{~nm}$, emission at 535/550 $\mathrm{nm}$ ), and High Q TR for Texas Red (excitation at 560/555 nm, emission at 645/675 nm) obtained from Chroma Technology (Brattleboro, VT). Image acquisition, processing, and overlay analysis were performed using IMAGE1 software (Universal Imaging, West Chester, PA).

Immunoelectron microscopy. For immunoelectron microscopy, lungs were prepared as described previously (34). Briefly, small biopsies were fixed by immersion in a mixture of $4 \%$ paraformaldehyde and $0.1 \%$ glutaraldehyde in $0.2 \mathrm{M}$ HEPES buffer $(\mathrm{pH} 7,4)$. The tissue blocks were infiltrated with $2.3 \mathrm{M}$ sucrose for 3-4 $\mathrm{h}$ and frozen in liquid nitrogen. The frozen samples were transferred to $0.5 \%$ uranyl acetate in methanol at $-90^{\circ} \mathrm{C}$ for at least $36 \mathrm{~h}$. The temperature was raised to $-45^{\circ} \mathrm{C}$ at a rate of $5^{\circ} \mathrm{C} / \mathrm{h}$. The samples were washed several times with pure methanol and transferred to Lowicryl HM 20 via HM20-methanol 1:1 and 2:1 for $2 \mathrm{~h}$ each. Blocks were polymerized under UV light for $2 \mathrm{~d}$ at $-45^{\circ} \mathrm{C}$. Ultrathin sections were labeled with monospecific surfactant antisera as described (34).

\section{In Vitro Analysis of SP-C Expression}

SP-C and EGFP / hSP-C expression constructs. A full-length human SP-C cDNA insert of 875 bp corresponding to the published sequence (Group II clones) of Warr et al. (26) was the generous gift of Dr. Philip Ballard. This insert was subcloned into the pcDNA3 eukaryotic expression vector polylinker at the EcoRI site as previously described for rat SP-C (35). The resultant 
wild-type human SP-C clone [termed pcDNA3-hSP-C $(6+)$ ] was then used as template for generation of a chimeric fusion protein consisting of EGFP and wild-type human SP-C (EGFP/hSP-C $\left.{ }^{1-197}\right)$ via a PCR as previously described $(19,36)$.

To generate the mutant EGFP/hSP-C ${ }^{\mathrm{L} 188 \mathrm{Q}}$, a two-primer, single-reaction PCR technique was also used with pcDNA3-hSP-C (6+) serving as template. The primers are shown in Table 1. Amplification produced a purified PCR insert containing the desired point mutation at codon 188 and lacking the $3^{\prime}$ untranslated region, which was ligated into $\mathrm{pEGFP-C_{1 }}$ after digestion with BamHI and BglII.

For construction of EGFP/hSP-C ${ }^{\mathrm{E} 66 \mathrm{~K}}$, mutagenesis was also performed by overlap extension PCR with the primer sets listed in Table 1. The resulting mutant insert, hSP-C $\mathrm{C}^{\mathrm{E} 66 \mathrm{~K}}$ containing the $3^{\prime}$ untranslated region was purified and ligated into pEGFP- $\mathrm{C}_{1}$ after digestion with $B g / \mathrm{II}$ and $\mathrm{BamHI}$.

The sequence fidelity of each generated insert was confirmed by automated DNA sequencing.

A549 cell line and transfection. The human lung epithelial cell line A549 originally obtained through the American Type Culture Collection (Manassas, VA) has been used in prior studies $(19,32,33,35,36)$. A549 cells grown to $50 \%$ confluence on glass coverslips were transiently transfected with EGFP/SP-C constructs $(10 \mu \mathrm{g} / \mathrm{dish}) \mathrm{CaPO}_{4}$ precipitation as previously described (32). Transfection efficiencies ranged from 10 to $20 \%$.

For studies of permeabilized cells, fixation by immersion of coverslips in $4 \%$ paraformaldehyde was followed by incubation with primary antisera for $1 \mathrm{~h}$ at room temperature followed by either secondary goat anti-mouse $\operatorname{IgG}$ monoclonal or secondary goat anti-rabbit IgG polyclonal antisera (32).

\section{RESULTS}

Sequence analysis of genomic DNA from the index patient revealed a heterozygous mutation in exon 2 of the SP-C gene (position $1509 \mathrm{G}>\mathrm{A}$ ) leading to GAG to AAG that results in substitution of a lysine for glutamic acid at codon 66 (SP$\mathrm{C}^{\mathrm{E} 66 \mathrm{~K}}$ ). The remainder SP-C sequence (exons 1-5) for both alleles corresponded to the SP-C sequence submitted by Glasser (GenBank Accession \# J03890). The E66K substitution was not present in either parent and was not found on 296 alleles from controls without lung disease indicating it was not a common polymorphism. Both parents were without pulmonary symptoms to date and had no history of previous lung disease.

The expression of SP-C ${ }^{\mathrm{E} 66 \mathrm{~K}}$ was associated with the presence of interstitial lung disease in the index patient. Hematoxylin and eosin staining of paraffin-embedded sections from an open-lung biopsy obtained at 2 mo of age (Fig. 1, $a$ and $b$ ) revealed the presence of cellular NSIP with thickened alveolar septa containing variable amounts of collagenous fibers. The cellular component of the intraalveolar septae consisted mainly of vimentin positive mesenchymal cells (Fig. 1c). Immunostaining for TTF-1, LCA (leukocyte common antigen), and CD3 revealed a hyperplasia of positive type II pneumocytes and the presence of a mild interstitial chronic inflammation with mainly CD3-positive T-lymphocytes (not shown). The interstitial lung disease was persistent and progressive. Highresolution CT scanning performed at $2 \mathrm{y}$ of age revealed the presence of interstitial infiltrates with some ground opacities (Fig. 2).

In addition to interstitial pneumonia, biochemical analysis of BAL revealed high levels of protein and phospholipid accompanied by an elevated concentration of SP-A (Table 2). In Figure $3 a$, thin layer chromatography of phospholipids performed on three BAL samples, collected at 2-wk intervals, showed, with respect to a patient without interstitial lung disease (control) (Fig. 3b), the complete absence of PG and an increase of sphingomyelin. The majority of PC was present in a disaturated form with palmitic acid representing $69.5 \%$ of fatty acids associated with this phospholipid. Apart from the lack of PG and lysoPC, the phospholipid composition of our patient was similar to that of a patient with alveolar proteinosis (Fig. 3c). By Western blotting, SP-A, SP-B, mature SP-C, and SP-D were all present in the BAL (Fig. 4a) and mature SP-C in both controls and index patient samples migrated in a similar fashion (Fig. 4b). Repeated surveillance failed to document the presence of Pneumocystis or other opportunistic infections. Conventional bacterial and viral cultures were also negative, demonstrating a lack of infectious organisms in this patient.

The distribution of the surfactant proteins in the lung of the index patient was assessed by immunofluorescence. Paraffin sections of the index patient (obtained from an open-lung biopsy) were stained for human proSP-C. Two populations of type 2 cells were identified. In approximately $90 \%$ of type II cells, proSP-C expression was detected in small endosome-like peripheral vesicles as well as some minimal staining at the level of the plasma membrane (Fig. $5 a$, arrowhead). In contrast, in tissue sections from an open lung biopsy from a patient with BPD ("BPD," Fig. 5c) and a specimen from a normal donor lung graft ("Donor," Fig. 5e), wild-type proSP-C was

Table 1. Primer sets used in PCR reactions for generation of EGFP/hSP-C fusion constructs

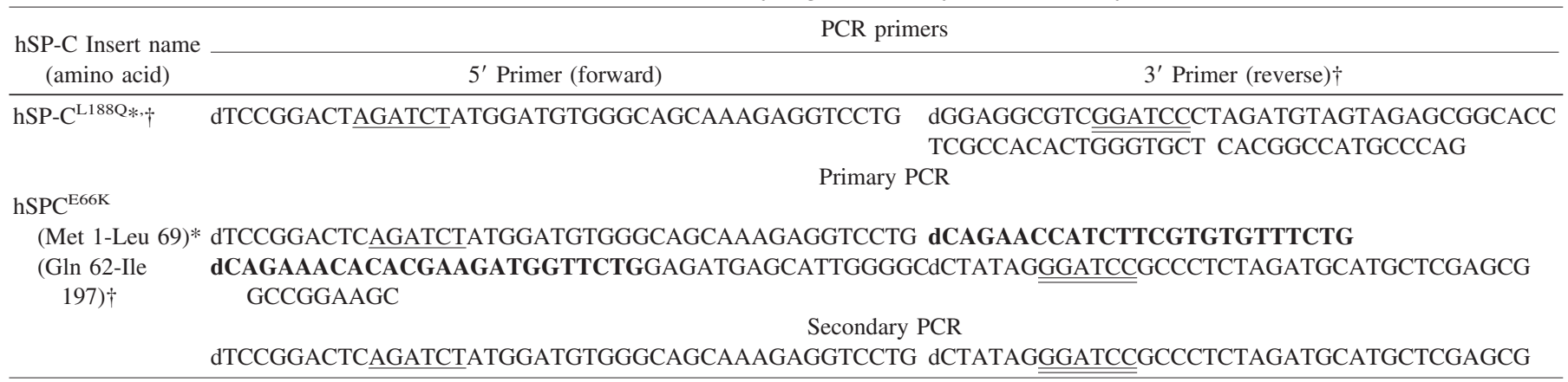

For all reactions of primary PCR, pcDNA3-hSP-C $(6+)$ was used as template. Overlapping primers permitting complementation in the secondary PCR to produce the full-length insert are highlighted in bold type.

* $5^{\prime}$ end of forward primer contains a BglII site $\left(5^{\prime}\right.$-AGATCT- $\left.3^{\prime}\right)$ for in-frame ligation into EGFP-C . $_{1}$.

$\dagger$ The $3^{\prime}$ end of reverse primer matches the polylinker of pcDNA3 and contains a BamHI site (5'-GGATCC-3'). Use of this primer resulted in inclusion of the $3^{\prime}$ untranslated region in the mutant construct. 


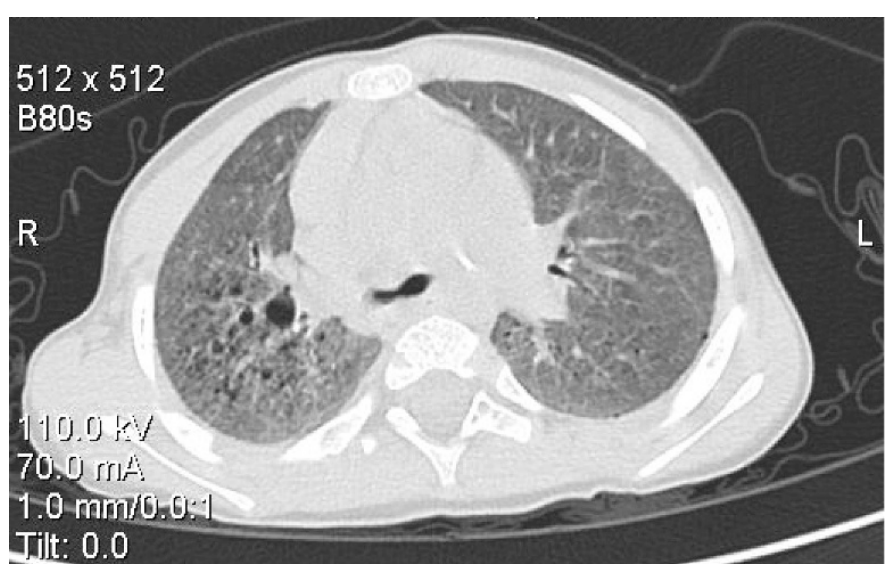

Figure 2. High-resolution $\mathrm{CT}$ scanning using intravenous contrast performed on the index patient at 24 mo of age revealed the presence of bilateral interstitial pneumonia.

Table 2. Composition of BAL fluid

\begin{tabular}{lc}
\hline \multicolumn{1}{c}{ Component } & Concentration $(\mu \mathrm{g} / \mathrm{mL})$ \\
\hline Total protein & $1119 \pm 470(38-670)$ \\
SP-A & $64 \pm 24(2-7)$ \\
Total phospholipid & $316 \pm 257(46-153)$ \\
SP-A/total phospholipid & $0.19 \pm 0.09(0.04-0.08)$ \\
\hline
\end{tabular}

Data are means \pm SD from six to nine determinations for the listed components in BAL from the index patient. In parentheses are the range of values for each variable from six babies of the same age (of Caucasian descent and from the same region of Italy), subjected to BAL using identical methods. BAL was requested for these infants as a routine investigation for a suspected pulmonary infection, and these culture results were negative.

associated with apical vesicles of type II pneumocytes. In about $10 \%$ of type II pneumocytes, a granular staining pattern consisting of cytosolic deposits of proSP-C with a nominal diameter of $\sim 2 \mu \mathrm{m}$ was observed (Fig. 6A). Rarely, larger sizes (diameter $\sim 7 \mu \mathrm{m}$ ) were detected (not shown). Corresponding to the immunohistochemical staining pattern for proSP-C, abnormal deposits of small vesicles were found in severely damaged type II pneumocytes (10\% of total type II cells examined) at the ultrastructural level (Fig. $6 B$ ). To further characterize these forms, an immunoelectron microscopic analysis was performed in which strong labeling of $10 \mathrm{~nm}$ gold particles for proSP-C was found over these regions (Fig. 6, $C$ and $D$ ). By contrast, SP-B (10-nm gold particles) was found in multivesicular bodies (Fig. $6 E$ ) and over the projection core of lamellar bodies in type II pneumocytes (Fig. $6 F$ ).

To directly assess the functional significance of the E66K substitution, in vitro trafficking studies were performed utilizing lung epithelial cells transfected with expression constructs encoding for fusion proteins of EGFP in either wild type SP-C or the E66K mutant form (Fig. 7). Control transfections using EGFP/hSP-C ${ }^{1-197}$ revealed protein expression in cytosolic vesicles of A549 cells. This compartment is CD63 positive (Fig. 7) and has been previously shown to be EEA-1 negative (19), consistent with targeting of wild-type fusion protein to acidic lysosomal-like organelles. Trafficking of the EGFP/ hSP-C ${ }^{\text {E66K }}$ mutant was markedly different, with distribution mainly in small cytosolic vesicles that were CD63 negative, EEA-1 positive consistent with accumulation in early endosomes (Fig. 7).
Two previously published SP-C mutations both located in another region of the proSP-C molecule have also been associated with interstitial lung disease (L188Q and $\Delta$ Exon 4) $(16,37)$. When compared with $\mathrm{hSP}-\mathrm{C}^{\mathrm{E} 66 \mathrm{~K}}$, expression of EGFP/ hSP-C ${ }^{\mathrm{L} 188 \mathrm{Q}}$ produced a different subcellular distribution in vitro. In A549 cells, this mutant developed perinuclear aggregation with ubiquitination of the accumulated protein (Fig. 7). In addition, similar to features observed previously with the hSP-C ${ }^{\Delta \text { Exon4 }}$ mutant (19). EGFP/ hSP-C $\mathrm{C}^{\text {L188Q }}$ did not colocalize with CD63 or EEA-1 (data not shown). Importantly, EGFP/hSP-C ${ }^{\mathrm{E} 66 \mathrm{~K}}$ was ubiquitin negative (Fig. 7, right panels) indicating that mutations located in two spatially distinct regions of the proSP-C molecule (proximal versus distal $\mathrm{COOH}$ propeptide) yield two distinct trafficking patterns in vitro.

\section{DISCUSSION}

Over the past two decades, our understanding of the biosynthetic pathway for SP-C has greatly improved. The proteolytic cleavage steps for processing of the SP-C propeptide, the structural domains that mediate protein trafficking, the subcellular compartments involved, the importance of proper protein folding, and the presence of an intact regulated secretory pathway for successful biosynthesis are now well accepted $(11,12,19,33,35,36)$. It has been demonstrated that alterations in the proSP-C sequence that result in either misfolding or mistargeting can induce formation of intracellular aggregates and/or ER retention. Recently, we have shown that a deletion of the exon 4 transcript of the SP-C gene found in association with idiopathic interstitial pneumonia (17) is characterized by similar defects in intracellular trafficking in vitro (19). The present study extends these observations through the characterization of a structurally distinct mutation in the SP-C gene, which, when detected in biopsy specimens or expressed in vitro, is associated with abnormal targeting of the protein and accumulation in early endosomal compartments. Thus, in contrast to previously described SP-C mutations, the E66K missense substitution (hSP-C ${ }^{\mathrm{E} 66 \mathrm{~K}}$ ) represents a class of spatially and functionally distinct mutations of proSP-C capable of producing chronic lung disease but are phenotypically distinct from their predecessors.

For many diseases, the homozygous expression of a mutant protein induces a global loss of function by interference with protein trafficking or function. In contrast, the heterozygous expression of a mutant allele is sometimes sufficient to induce pathology as represented by a diverse set of chronic, degenerative disorders in a variety of organ systems including brain, liver, and lung. Alzheimer's disease, Parkinson's disease, alpha-1 antitrypsin, amyloidosis, spinocerebellar ataxia, and Charcot-Marie-Tooth disease are all associated with expression of a mutant protein that undergoes a fatal conformational rearrangement (38). At both a recent international conference on $\alpha-1$ antitrypsin deficiency as well as a workshop on protein processing and degradation in the lung sponsored by the National Heart, Lung, and Blood Institute, the mechanisms by which cells respond to production of abnormal protein conformers and how such misfolded proteins cause cytotoxicity 

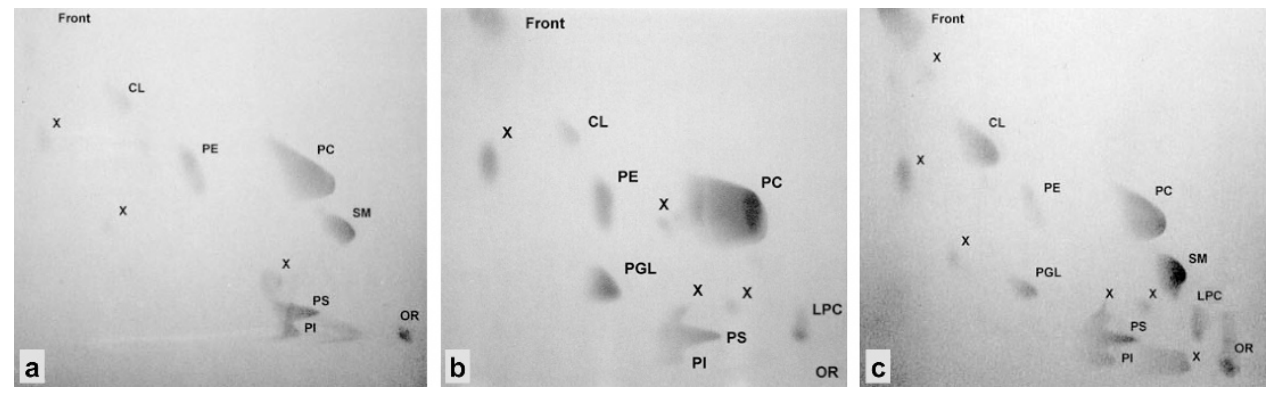

Figure 3. Surfactant phospholipid analysis. Surfactant (200 $\mu \mathrm{g}$ phospholipid) from the index patient (a), from an infant undergoing BAL to exclude infection $(b)$, and from of an adult patient with alveolar proteinosis $(c)$ were each extracted and the lipids subjected to two-dimensional thin layer chromatography as described in "Methods." OR, origin; SM, sphingomyelin; PI, phosphatidylinositol; PS, phosphatidylserine; LPC, lysophosphatidylcholine; PE, phosphatidylethanolamine; CL, cardiolipin; PGL, phosphatidylglycerol; X, unknown,

a

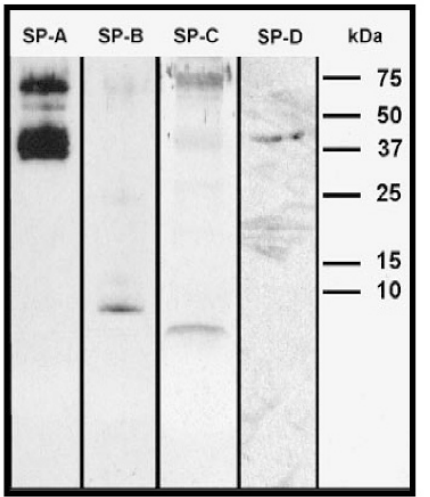

b

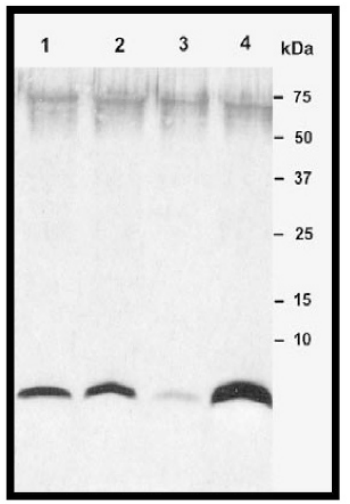

Figure 4. Western blotting for surfactant proteins. (a) Total protein from BAL from the index patient was separated by SDS-PAGE and transferred to nitrocellulose as detailed in "Methods." Each lane was probed with monospecific antisera against SP-A, SP-B, mature SP-C, or SP-D and immunoreactive proteins were visualized by chemiluminescence. The position of molecular weight standards is shown at right. The amounts of BAL used per lane were 10 $\mu \mathrm{L}$ for SP-A and SP-B, $150 \mu \mathrm{L}$ for SP-C, and $240 \mu \mathrm{L}$ for SP-D. (b) Western blotting of total BAL protein for mature SP-C was performed on the index patient (lane 2) and compared with BAL recovered from three controls performed to exclude infection (lanes 1, 3, 4). Each lane contained $30 \mu \mathrm{g}$ of total protein. Mature SP-C was detected as a low molecular weight monomer in all four samples (arrowhead).

were highlighted as important emerging questions $(39,40)$. Cells have a limited repertoire for disposal of abnormal products. Normally, degradation of both integral membrane proteins as well as secreted peptides unable to fold in the ER or to traffic anterograde involves one of four pathways: 1 ) retrograde routing to cytosolic proteasomes, 2) diversion to the constitutive secretory pathway, 3) accumulation in endosomes/ lysosomes, or 4) development of autophagosomes. Data showing a tendency of mutant proSP-C to either aggregate or be rerouted to any of these compartments would be consistent with this concept of conformational disease.

The role of SP-C mutations in producing conformational mediated disease in the lung was initially supported by two early reports of patients with heterozygous expression of TWO different mutant proSP-C forms in association with interstitial lung disease $(16,17)$. The first SP-C mutation, $\mathrm{c} 460+1 \mathrm{G}>\mathrm{A}$, was found on one allele both in a full-term infant with histologic features of NSIP and in the mother whose lung pathology was consistent with UIP produced alternate splicing of the

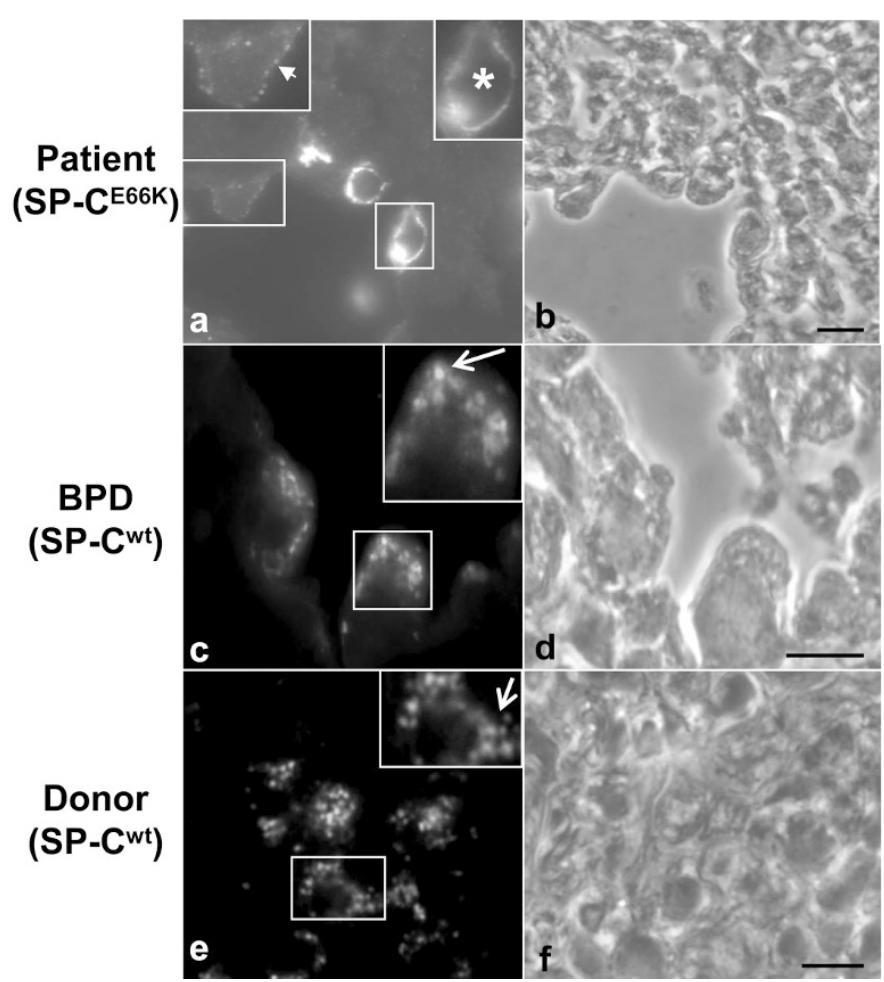

Figure 5. Expression of mutant SP-C $\mathrm{E}^{\mathrm{E} 6 \mathrm{~K}}$ in lung tissue. Fluorescence $(a, c$, $e$ ) and phase contrast $(b, d, f)$ micrographs of paraffin lung sections from the index patient with heterozygous expression of the E66K mutation $(a, b)$, from a recipient lung of a patient with BPD undergoing bilateral lung transplantation $(c, d)$, and from a normal donor lung $(e, f)$ stained for proSP-C using anti-NPROSP-C as described in "Methods." Type II cells from the E66K mutant lung (a) exhibit proSP-C localization in small subplasma membrane vesicles (inset, arrowhead). In a minority of cells, larger aggregates of proSP-C were also observed (inset, asterisk). In both normal donor lung and BPD lung, proSP-C expression was limited to large cytoplasmic organelles at the apex of the cell (inset, $c$ and $e$, arrows).

SP-C mRNA, deletion of exon 4, and resultant production of a defective proprotein foreshortened by 37 amino acids (17). The second mutation was an exon $5 \mathrm{~T}>\mathrm{A}$ transversion, which substitutes glutamine for a conserved leucine at residue 188 of the $\mathrm{COOH}$ propeptide ("L188Q"), was present in a kindred with histologic features of UIP in adults and NSIP in children (16). Of note, the distal $\mathrm{COOH}$ region of proSP-C $\left(\mathrm{F}^{94}-\mathrm{I}^{197}\right)$ has recently been structurally linked with an emerging family of several previously unrelated proteins all containing a novel 


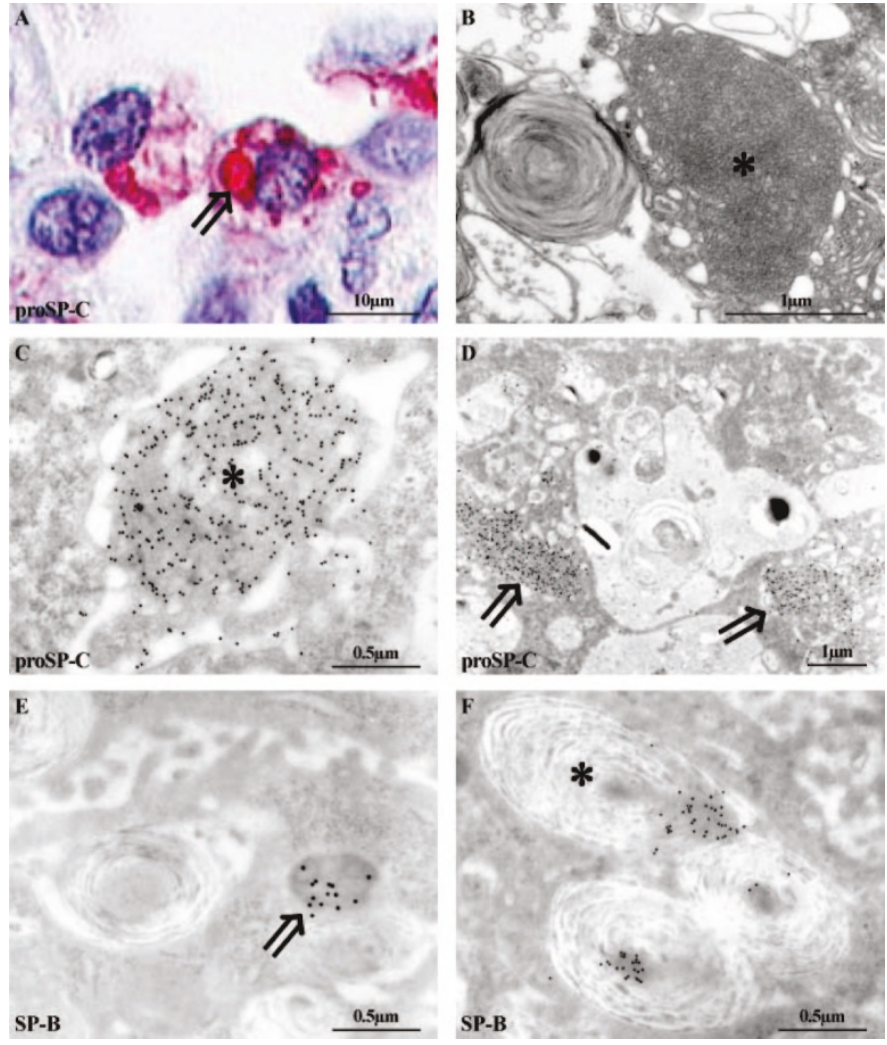

Figure 6. hSP-C $\mathrm{C}^{\mathrm{E} 66 \mathrm{~K}}$ accumulates in nonlamellar body intracellular compartments. (A) Immunostaining of lung section from index patient for proSP-C revealed a granular immunohistochemical pattern in some cells with formation of aggregates of proSP-C (arrow). (B) Ultrastructural analysis using EM on a specimen prepared from the same sample showing the presence of both lamellar bodies and amorphous intracellular aggregates in small vesicles (asterisk) in severely damaged type II pneumocytes. $(C-F)$ Immunogold EM was performed on the same biopsy specimen from the index patient as described in "Methods." Using anti-NPROSP-C and 10-nm gold particles, a strong labeling for proSP-C was observed over the aggregates (C, asterisk). Nearly all aggregates containing proSP-C were found in close proximity to a swollen endoplasmic reticulum ( $D$, double arrows). Substituting a polyclonal anti-SP-B antibody with 10-nm gold particles $(E-F)$, SP-B isoforms were detected in multivesicular bodies ( $E$, double arrow) and over the projection core of lamellar bodies in type II pneumocytes $(F$, asterisk).

BRI domain (BRICHOS) (18). The exact function of BRI family members is unknown, however, degenerative dementia with CNS amyloid formation in kindreds expressing BRI mutations is well described (41). Using EGFP fusion proteins, we have demonstrated induction of ubiquinated protein aggregates in vitro by both hSP-C ${ }^{\Delta \text { Exon4 }}(19)$ and hSP-C ${ }^{\text {L188Q }}$ (Fig. 7 ), which have subsequently been shown to be toxic to the developing mouse lung in vivo (20).

In contrast to these mutations, the E66K substitution in proSP-C lies more proximal to BRICHOS and as such would not be expected to disrupt cysteine-mediated folding, as has been the case for either hSP-CL ${ }^{188 \mathrm{Q}}$ or hSP-C $\mathrm{C}^{\Delta \text { Exon4 }}$. Expression of hSP-C ${ }^{\mathrm{E} 66 \mathrm{~K}}$ in vitro was not associated with the formation of ubiquitin-labeled aggregates but instead was found in EEA1-positive vesicles. Furthermore, the clinical picture of the patient differed from the previous patient series because the interstitial pneumonia was complicated by coexistence of alveolar lipoproteinosis and the presence of intracellular
proSP-C aggregates (Fig. 5). Interestingly, it has been recognized that patients with Hermansky-Pudlak syndrome (HPS) can develop pulmonary fibrosis (42). HPS is a polygenetic disorder associated with defective vesicle formation including abnormal melanosomes, platelet granules, lysosomes, and lamellar bodies (43). Mice with HPS1 and HPS2 gene mutations demonstrate increased lung levels of lysosomal enzymes and phospholipids in conjunction with fibrosis suggesting that altered vesicular trafficking and accumulation of abnormal protein can promote lung inflammation and fibrosis (44).

In the current work, the BAL of the index patient contained detectable mature SP-C. This is in contrast to patients with heterozygous expression of the hSP-C ${ }^{\Delta \text { Exon } 4}$ allele in which mature SP-C was absent suggesting the presence of a dominant negative effect upon SP-C biosynthesis by that mutant allele (17). Because SP-B was present in the patients with the $\Delta$ exon4 mutation, the contribution of the lack of SP-C to the underlying lung pathology is unclear. The SP-C null mouse has been shown to be viable (14), however, a recent report suggests that when SP-C $-/-$ mice are back-crossed onto a different strain, they develop emphysema (15). Because SP-C was still detectable in the current patient, it is unlikely that the pathology of interstitial pneumonias (UIP, NSIP) associated with SP-C mutations is due simply to a lack of SP-C (dominant negative effect). More plausible, the data suggest that SP-C mutations induce a toxic gain of function that is a consequence of the resultant abnormalities in protein trafficking.

The E66K substitution in the SP-C gene of this child is the result of a sporadic mutation. The clinical picture of hSP-C ${ }^{\mathrm{E} 66 \mathrm{~K}}$ is similar to that of two other recently reported human SP-C mutations $(45,46)$. A sporadic substitution of threonine for isoleucine at codon 73 was noted in an infant with wellcharacterized NSIP pattern on histopathology and PAS (periodic acid-Schiff)-positive material (45). In vitro expression of hSP-C ${ }^{\mathrm{I73T}}$ / EGFP fusion protein in A549 cells was associated with deposition in early endosomes. A recent preliminary study has reported additional heterozygous hSP-C ${ }^{\mathrm{I} 73 \mathrm{~T}}$ mutations in association with interstitial lung disease, some of which occurred spontaneously in several unrelated patients (37). In addition to multiple cases of I73T substitutions, an in-frame 9-bp deletion spanning codons 91-93 in exon 3 of the SP-C gene present on one allele was described in a patient with ILD undergoing lung transplantation. Neither parent carried this deletion. By immunofluorescence, proSP-C in the transplanted lung was aggregated within type II cells in a compartment separate from SP-B (46). Taken together, the de novo occurrence of all three of these mutations (hSP-C ${ }^{\mathrm{E} 66 \mathrm{~K}}$, hSP-C ${ }^{\mathrm{I} 73 \mathrm{~T}}$, and hSP-C ${ }^{\Delta 91-93}$ ) in relation to the development of chronic lung disease and located within 30 amino acids of each other, lends support to the pathogenicity of mutations in the proximal $\mathrm{COOH}$ flanking region. Furthermore, the nonBRICHOS portion of proSP-C $\left(\mathrm{H}^{59}-\mathrm{T}^{93}\right)$ could represent a genetic hot-spot for spontaneous mutations in the SP-C gene.

Analogous to what has been developed for understanding the pathophysiology of the cystic fibrosis transmembrane receptor, a working model to explain the contrasts between phenotypes found with the two major forms of SP-C mutations reported to date is shown in Figure 8. In normal biosynthesis, proSP-C is 

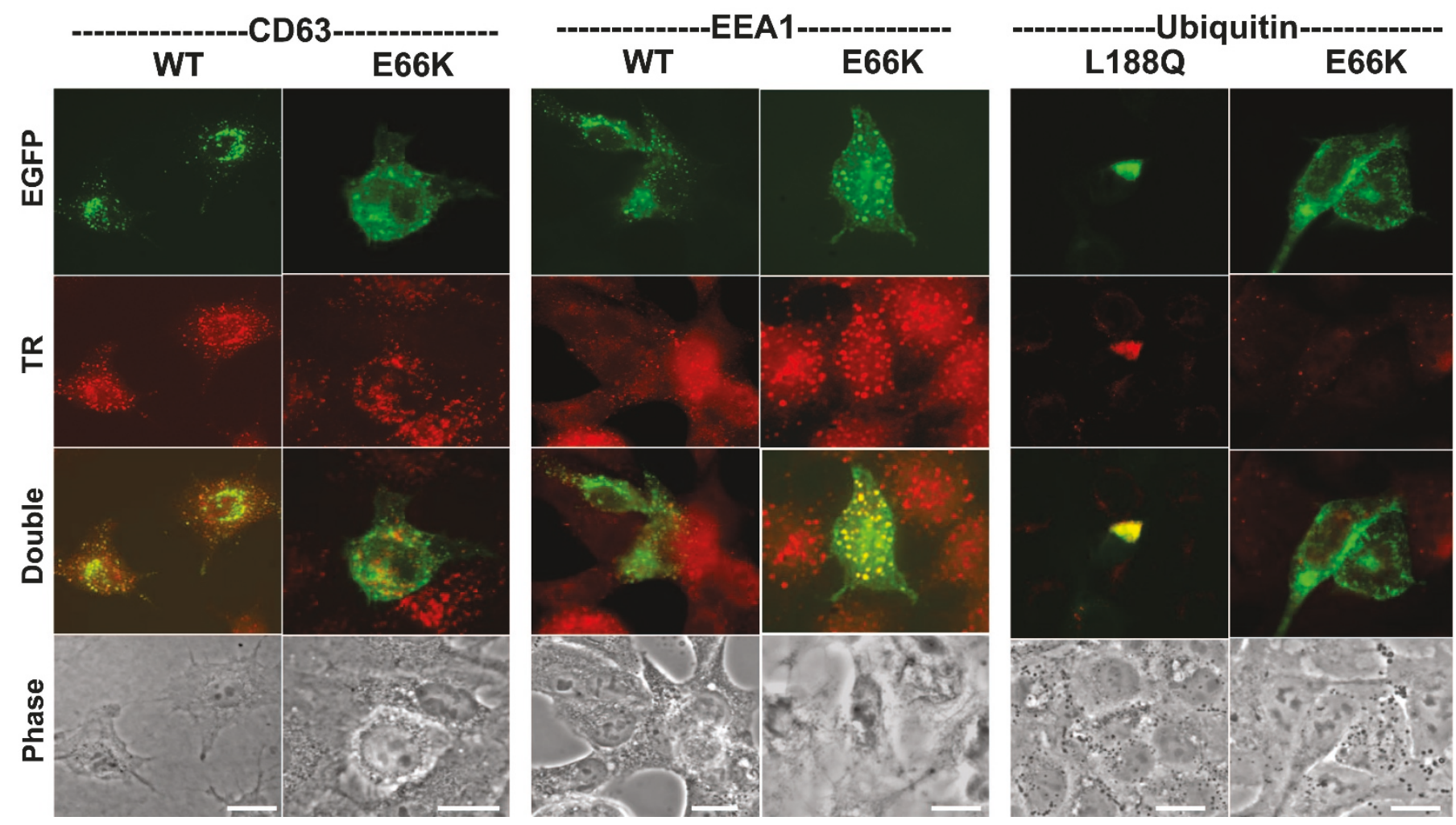

Figure 7. Expression of EGFP tagged human SP-C mutants in vitro. A549 cells grown on glass coverslips to $50-60 \%$ confluence were transfected with $10 \mu \mathrm{g}$ each of plasmids containing cDNA constructs for expression of EGFP fusion proteins containing either wild-type SP-C (hSP-C ${ }^{1-197)}$ (columns 1, 3), hSP-C ${ }^{\text {E66K }}$ (columns 2, 4, 6), or hSP-C ${ }^{\mathrm{L} 188 \mathrm{Q}}$ (column 7) using $\mathrm{CaPO}_{4}$ precipitation as described in "Methods." Forty-eight hours after transfection, cells were fixed, permeabilized, and stained with primary monoclonal EEA-1 antiserum, polyclonal antiCD-63, or monoclonal anti-ubiquitin followed by IgG-specific secondary Texas Red (TR)-labeled antisera. Images were acquired by video fluorescence microscopy using High Q FITC filter package for EGFP fusions or a High Q Texas Red filter package for marker antibody labeling. When subjected to color overlay using IMAGE 1 software (third row), areas of colocalization appear as yellow. Corresponding phase images for each set are shown at the bottom. The majority of EGFP/hSP-C ${ }^{\mathrm{E} 66 \mathrm{~K}}$ was associated with EEA-1 staining while EGFP/hSP$\mathrm{C}^{\mathrm{L} 188 \mathrm{Q}}$ formed ubiquinated perinuclear aggregates. Images are representative of 10 separate experiments for each construct and $>50$ cells for each experiment.

trafficked as a homodimer from the ER through the Golgi to the multivesicular body and ultimately to the lamellar body where the mature protein is secreted with phospholipid and SP-B. In contrast, expression of mutant forms of SP-C can result in one of two fates. In the first pathway, BRICHOS mutants (such as

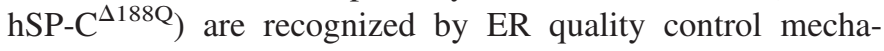
nisms. Termed ER-associated degradation (ERAD) this pathway involves the ubiquitination of the abnormal protein and targeting to the proteasome for disposal. If overwhelming to the proteasome, aggregated proteins can be diverted retrograde to a microtubule-dependent inclusion body termed the aggresome (47). Because of the oligomerization, the wild-type allele product is also routed here leading to a dominant negative effect imposed by the ubiquitinated mutant resulting in a lack of SP-C (19). However, in addition, there appears to be a toxic gain of function. Retention of protein in the ER can itself initiate an inflammatory response (ER overload response) (48). Recent data by Bridges et al. (20) suggests that overexpression of hSP-C $\mathrm{C}^{\Delta \text { Exon4 }}$ in vitro can activate a Bip-dependent ER overload response.

In contrast to BRICHOS mutations, for E66K as well as other mutants within the proximal $\mathrm{COOH}$ domain, aggresome formation does not occur. We propose a second pathway, whereby substitutions in the nonBRICHOS region (e.g. hSP$\left.\mathrm{C}^{\mathrm{E} 66 \mathrm{~K}}\right)$ result in a milder protein phenotype not severe enough to grossly misfold and trigger the ER stress response (Fig. 8). Because proSP-C is processed as an integral membrane protein, diversion of the protein away from the regulated secretory pathway would limit the protein's ability to be properly processed. Thus, by either fusion of the constitutive vesicles containing membrane bound mutant proSP-C to the plasma membrane and bulk membrane recycling mechanisms or transport of mutant proSP-C directly from the trans-Golgi, endosomal accumulation can occur (49). Unlike either normal anterograde trafficking or ubiquitination-mediated proteasomal routing, this entry into default pathways does not require a strong trafficking signal. Heteromers containing wild-type protein would present an overriding signal to continue anterograde, and mutant protein is unlikely to function as a dominant negative. We have shown in vitro that a different experimental SP-C mutant that lacks $\mathrm{NH}_{2}$ targeting signals can be trafficked anterograde via heteromeric association with co-transfected wild-type protein (36). Thus, in parallel with abnormal diversion of mutant hSP-C ${ }^{\mathrm{E} 66 \mathrm{~K}}$ to endosomes, a portion of both the mutant and wild-type isoforms could also undergo normal trafficking and processing as heterodimers to the mature protein and $\mathrm{SP}_{-} \mathrm{C}_{3.7}$ has been detected in lavage. Importantly our findings regarding $\mathrm{hSP}-\mathrm{C}^{\mathrm{E} 66 \mathrm{~K}}$ indicate that the pathogenicity from expression of this mutant cannot come from the lack of SP-C but rather represent a disruption of normal cellular 


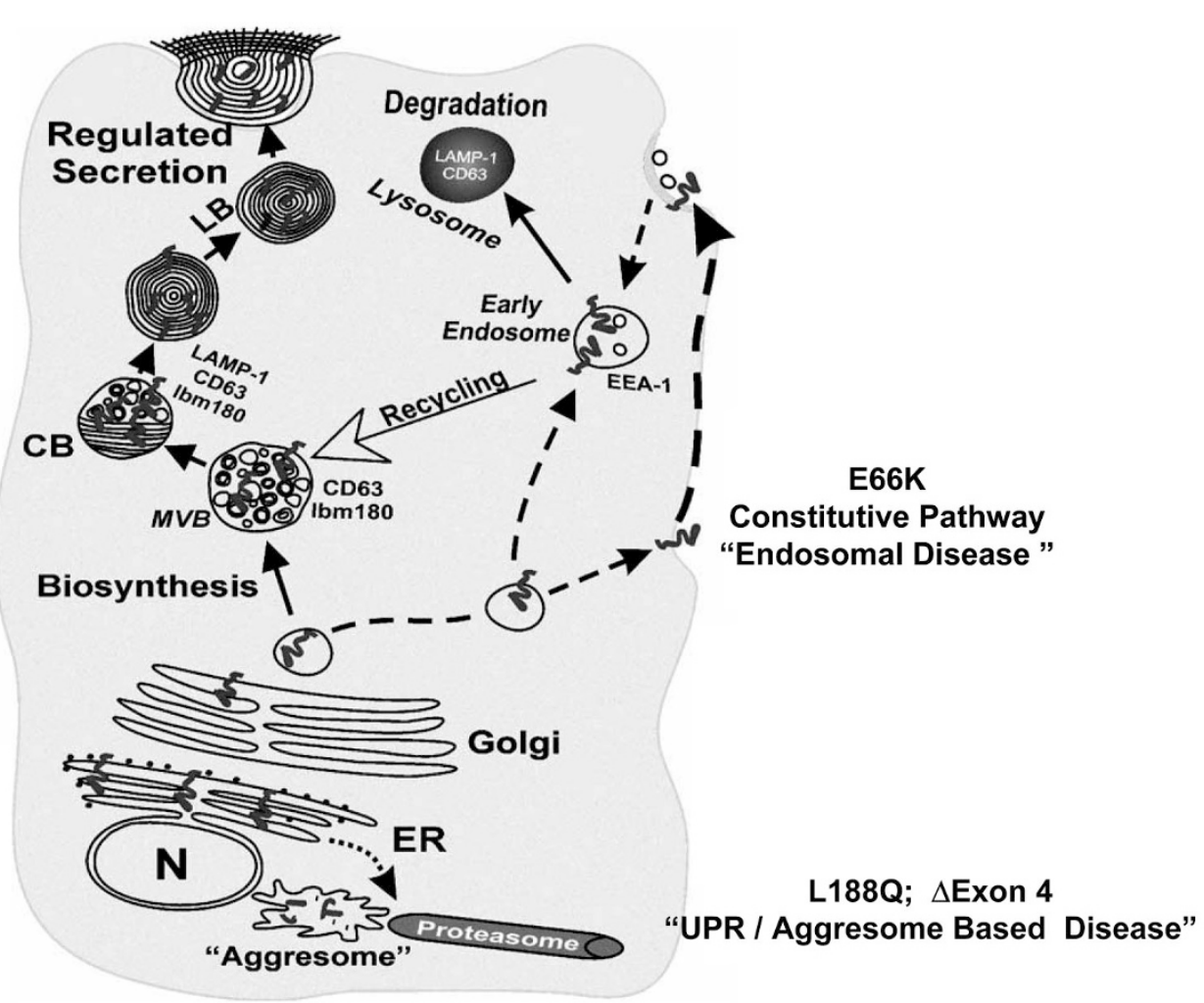

Figure 8. Model for aberrant trafficking of human SP-C mutants associated with ILD. Schematic diagram showing possible fates for expressed human SP-C proteins. Normal SP-C biosynthesis proceeds via sorting and delivery of proSP- $\mathrm{C}_{21}$ to cytosolic processing sites in the regulated secretory pathway including ER, Golgi, cytosolic vesicles, multivesicular bodies $(M V B)$, composite bodies $(C B)$, and lamellar bodies $(L B)$ where it is co-secreted with SP-B and lipid (solid arrows). Reuptake of phospholipid and surfactant proteins occurs via endocytosis, early endosome incorporation, and recycling via MVB or degradation in lysosomes. The previously published mutants hSP-C ${ }^{\mathrm{L} 188 \mathrm{Q}}$ and hSP-C $\Delta$ Exon4 overwhelm ER quality control mechanisms forming large toxic intracellular aggregates (aggresomes) (dotted arrows). In contrast, mutants of the proximal flanking $\mathrm{COOH}$ propeptide such as hSP-C $\mathrm{C}^{\mathrm{E} 66 \mathrm{~K}}$ are diverted from normal biosynthesis and accumulate in the endosomal pathway directly or after deposition in the plasma membrane (dashed arrows) and inhibit the recycling pathway. UPR, unfolded protein response; ibm180, ABCA3 gene produt; LAMP-1, lysosome associated membrane protein.

function by accumulation of mutant forms in atypical intracellular compartments (toxic gain of function).

Our immunocytochemistry indicates that aggregation is occurring in the histopathology sections. We have noted that up to $10 \%$ of the cells contain intracellular aggregates of proSP-C. There are two possibilities for the heterogeneity in the cellular expression pattern. Different alleles are somatically expressed in different type II cells. Alternatively, temporal and spatial heterogeneity in the level of expression of both alleles is occurring. Given that the biopsy specimen represents but a single time point, the dynamic formation of intracellular aggregates is not experimentally assessable from this data. The transmission of proteotoxicity across cellular compartments is an emerging area of investigation. Recently, it has been shown by Jin et al. (50) that intracellular accumulation of amyloid precursor protein disrupts endosome function in the Niemannpick type $\mathrm{C}$ disease. Given the similar amyloidgenic properties of SP-C (51-53), it seems plausible that endosomal accumulation and aggregation of proSP-C leading to epithelial cell dysfunction results via a similar pathway. The accumulation of mutant protein in early endosomes as we observed could result in impairment of endocytosis leading to the extracellular accumulation of phospholipids and SP-A found in this patient.

In summary, we have characterized the phenotype of a patient with interstitial pneumonia, alveolar proteinosis, and a heterozygous mutation in the surfactant protein $\mathrm{C}$ gene. In contrast to previously reported SP-C mutations, this substitution represents a novel functional isoform in a spatially distinct region of the molecule. Both in vitro and in vivo data are compatible with diversion of the mutant protein to early endosomes and other nonlamellar body compartments. Further details of the molecular mechanisms translating the expression of the mutant protein in this compartment with the development of pulmonary fibrosis and lipoproteinosis will require development of long-term expression models such as transgenic mice, which are currently underway.

Acknowledgments. The authors thank Dr. Larry Nogee of Johns Hopkins University for advice regarding methodological development of PCR-based sequencing for the patient samples. We also thank Drs. Linda Gonzalez and Philip Ballard of Children's Hospital in Philadelphia for provision of control lung tissue samples through the Tissue Core of the SCOR grant in Lung Development (National Institutes of Health P50-HL56401).

\section{REFERENCES}

1. Griese M 1999 Pulmonary surfactant in health and human lung diseases: state of the art. Eur Respir J 13:1455-1476 
2. Gunther A, Siebert C, Schmidt R, Ziegler S, Grimminger F, Yabut M, Temmesfeld B, Walmrath D, Morr H, Seeger W 1996 Surfactant alterations in severe pneumonia, acute respiratory distress syndrome, and cardiogenic lung edema. Am J Respir Crit Care Med 153:176-184

3. Savani RC, Godinez RI, Godinez MH, Wentz E, Zaman A, Cui Z, Pooler PM, Guttentag SH, Beers MF, Gonzales LW, Ballard PL 2001 Respiratory distress after intratracheal bleomycin: selective deficiency of surfactant proteins B and C. Am J Physiol Lung Cell Mol Physiol 281:L685-L696

4. Russo TA, Bartholomew LA, Davidson BA, Helinski JD, Carlino UB, Knight III PR, Beers MF, Atochina EN, Notter RH, Holm BA 2002 Total extracellular surfactant is increased but abnormal in a rat model of gram-negative bacterial pneumonia. Am J Physiol Lung Cell Mol Physiol 283:L655-L663

5. Haczku A, Atochina EN, Tomer Y, Chen H, Scanlon ST, Russo SJ, Xu J, Panettieri RA Jr, Beers MF 2001 Aspergillus fumigatus-induced allergic airway inflammation alters surfactant homeostasis and lung function in BALB/c Mice. Am J Respir Cell Mol Biol 25:45-50

6. Seymour JF, Presneill JJ 2002 Pulmonary alveolar proteinosis: progress in the first 44 years. Am J Respir Crit Care Med 166:215-235

7. Hawgood S, Poulain FR 2001 The pulmonary collectins and surfactant metabolism. Annu Rev Physiol 63:495-519

8. Weaver TE, Conkright JJ 2001 Functions of surfactant proteins B and C. Annu Rev Physiol 63:555-578

9. Solarin KO, Wang WJ, Beers MF 2001 Synthesis and post-translational processing of surfactant protein C. Pediatr Pathol Mol Med 20:471-500

10. Beers MF, Kim CY, Dodia C, Fisher AB 1994 Localization, synthesis, and processing of surfactant protein SP-C in rat lung analyzed by epitope-specific antipeptide antibodies. J Biol Chem 269:20318-20328

11. Johnson AL, Braidotti P, Pietra GG, Russo SJ, Kabore A, Wang WJ, Beers MF 2001 Post-translational processing of surfactant protein-C proprotein: targeting motifs in the $\mathrm{NH}(2)$-terminal flanking domain are cleaved in late compartments. Am J Respir Cell Mol Biol 24:253-263

12. Beers MF, Lomax C 1995 Synthesis and processing of hydrophobic surfactant protein C by isolated rat type II cells. Am J Physiol 269:L744-L753

13. Beers MF 1996 Inhibition of cellular processing of surfactant protein $\mathrm{C}$ by drugs affecting intracellular pH gradients. J Biol Chem 271:14361-14370

14. Glasser SW, Burhans MS, Korfhagen TR, Na CL, Sly PD, Ross GF, Ikegami W, Whitsett JA 2001 Altered stability of pulmonary surfactant in SP-C-deficient mice. Proc Natl Acad Sci USA 98:6366-6371

15. Glasser SW, Detmer EA, Ikegami M, Na CL, Stahlman MT, Whitsett JA 2003 Pneumonitis and emphysema in SP-C gene targeted mice. J Biol Chem 278:1429114298

16. Thomas AQ, Lane K, Phillips J 3rd, Prince M, Markin C, Speer M, Schwartz DA, Gaddipati R, Marney A, Johnson J, Roberts R, Haines J, Stahlman M, Loyd JE 2002 Heterozygosity for a surfactant protein $\mathrm{C}$ gene mutation associated with usua interstitial pneumonitis and cellular nonspecific interstitial pneumonitis in one kindred. Am J Respir Crit Care Med 165:1322-1328

17. Nogee LM, Dunbar III AE, Wert SE, Askin F, Hamvas A, Whitsett JA 2001 A mutation in the surfactant protein $\mathrm{C}$ gene associated with familial interstitial lung disease. N Engl J Med 344:573-579

18. Sanchez-Pulido L, Devos D, Valencia A 2002 BRICHOS: a conserved domain in proteins associated with dementia, respiratory distress and cancer. Trends Biochem Sci 27:329-332

19. Wang WJ, Mulugeta S, Russo SJ, Beers MF 2003 Deletion of exon 4 from human surfactant protein $\mathrm{C}$ results in aggresome formation and generation of a dominan negative. J Cell Sci 116:683-692

20. Bridges JP, Wert SE, Nogee LM, Weaver TE 2003 Expression of a human surfactan protein $\mathrm{C}$ mutation associated with interstitial lung disease disrupts lung developmen in transgenic mice. J Biol Chem 278:52739-52746

21. Beers MF, Bates SR, Fisher AB 1992 Differential extraction for the rapid purification of bovine surfactant protein B. Am J Physiol 262:L773-L778

22. Schmidt R, Steinhilber W, Ruppert C, Daum C, Grimminger F, Seeger W, Gunthe A 2002 An ELISA technique for quantification of surfactant apoprotein (SP)-C in bronchoalveolar lavage fluid. Am J Respir Crit Care Med 165:470-474

23. Ross GF, Ikegami M, Steinhilber W, Jobe AH 1999 Surfactant protein C in fetal and ventilated preterm rabbit lungs. Am J Physiol 277:L1104-L1108

24. Glasser SW, Korfhagen TR, Perme CM, Pilot-Matias TJ, Kister SE, Whitsett JA 1988 Two SP-C genes encoding human pulmonary surfactant proteolipid. J Biol Chem 263:10326-10331

25. Hatzis D, Deiter G, deMello DE, Floros J 1994 Human surfactant protein-C: genetic homogeneity and expression in RDS; comparison with other species. Exp Lung Res 20:57-72

26. Warr RG, Hawgood S, Buckley DI, Crisp TM, Schilling J, Benson BJ, Ballard PL, Clements JA, White RT 1987 Low molecular weight human pulmonary surfactant protein (SP5): isolation, characterization, and cDNA and amino acid sequences. Proc Natl Acad Sci U S A 84:7915-7919

27. Polacheck I, Cabib E 1981 A simple procedure for protein determination by the Lowry method in dilute-solutions and in the presence of interfering substances. Anal Biochem 117:311-314
28. Bartlett GR 1959 Phosphorous assay in column chromatography. J Biol Chem 234:466-468

29. Poorthuis BJ, Yazaki PJ, Hostetler KY 1976 An improved two dimensional thin-layer chromatography system for separation of phosphatidylglycerol and its derivatives. J Lipid Res 17:433-437

30. Baritussio A, Alberti A, Quaglino D, Pettenazzo A, Dalzoppo D, Sartori L, PasqualiRonchetti I 1994 SP-A, SP-B, and SP-C in surfactant subtypes around birth: reexamination of alveolar life cycle of surfactant. Am J Physiol 266:L436-L447

31. Schagger H, von Jagow G 1987 Tricine-sodium dodecyl sulfate-polyacrylamide gel electrophoresis for the separation of proteins in the range from 1 to $100 \mathrm{kDa}$. Anal Biochem 166:368-379

32. Russo SJ, Wang W, Lomax CA, Beers MF 1999 Structural requirements for intracellular targeting of SP-C. Am J Physiol 277:L1034-L1044

33. Kabore AF, Wang WJ, Russo SJ, Beers MF 2001 Biosynthesis of surfactant protein $\mathrm{C}$ : characterization of aggresome formation by EGFP chimeras containing propeptide mutants lacking conserved cysteine residues. J Cell Sci 114:293-302

34. Brasch F, Ten Brinke A, Johnen G, Ochs M, Kapp N, Muller KM, Beers MF, Fehrenbach H, Richter J, Batenburg JJ, Buhling F 2002 Involvement of cathepsin H in the processing of the hydrophobic surfactant-associated protein $\mathrm{C}$ in type II pneumocytes. Am J Respir Cell Mol Biol 26:659-670

35. Beers MF, Lomax CA, Russo SJ 1998 Synthetic processing of surfactant protein C by alveolar epithelial cells. The $\mathrm{COOH}$ terminus of proSP-C is required for posttranslational targeting and proteolysis. J Biol Chem 273:15287-15293

36. Wang WJ, Russo SJ, Mulugeta S, Beers MF 2002 Biosynthesis of surfactant protein C (SP-C). Sorting of SP-C proprotein involves homomeric association via a signal anchor domain. J Biol Chem 277:19929-19937

37. Nogee LM, Dunbar III AE, Wert S, Askin F, Hamvas A, Whitsett JA 2002 Mutations in the surfactant protein $\mathrm{C}$ gene associated with interstitial lung disease. Chest 121:20S-21S

38. Carrell RW, Lomas DA 2002 Alpha1-antitrypsin deficiency-a model for conformational diseases. N Engl J Med 346:45-53

39. Kopito RR, Ron D 2000 Conformational disease. Nat Cell Biol 2:E207-E209

40. Zeitlin PL, Gail DB, Banks-Schlegel S 2003 Protein processing and degradation in pulmonary health and disease. Am J Respir Cell Mol Biol 29:642-645

41. Vidal R, Revesz T, Rostagno A, Kim E, Holton JL, Bek T, Bojsen-Moller M, Braendgaard H, Plant G, Ghiso J, Frangione B 2000 A decamer duplication in the 3 region of the BRI gene originates an amyloid peptide that is associated with dementia in a Danish kindred. Proc Natl Acad Sci U S A 97:4920-4925

42. Nakatani Y, Nakamura N, Sano J, Inayama Y, Kawano N, Yamanaka S, Miyagi Y, Nagashima Y, Ohbayashi C, Mizushima M, Manabe T, Kuroda M, Yokoi T, Matsubara O 2000 Interstitial pneumonia in Hermansky-Pudlak syndrome: significance of florid foamy swelling/degeneration (giant lamellar body degeneration) of type-2 pneumocytes. Virchows Arch 437:304-313

43. Swank RT, Novak EK, McGarry MP, Zhang Y, Li W, Zhang Q, Feng L 2000 Abnormal vesicular trafficking in mouse models of Hermansky-Pudlak syndrome. Pigment Cell Res 13:59-67

44. Swank RT, Novak EK, McGarry MP, Rusiniak ME, Feng L 1998 Mouse models of Hermansky Pudlak syndrome: a review. Pigment Cell Res 11:60-80

45. Brasch F, Griese M, Tredano M, Johnen G, Ochs M, Rieger C, Mulugeta S, Muller $\mathrm{KM}$, Bahuau M, Beers MF 2004 Interstitial lung disease in a baby with a de novo mutation in the SFTPC gene. Eur Respir J 24:30-39

46. Hamvas A, Nogee LM, White FV, Schuler P, Hackett BP, Huddleston CB, Mendeloff EN, Hsu FF, Wert SE, Gonzales LW, Beers MF, Ballard PL 2004 Progressive lung disease and surfactant dysfunction with a deletion of surfactant protein $\mathrm{C}$ gene. Am J Respir Cell Mol Biol 30:771-776

47. Kopito RR 2000 Aggresomes, inclusion bodies and protein aggregation. Trends Cell Biol 10:524-530

48. Kim PS, Arvan P 1998 Endocrinopathies in the family of endoplasmic reticulum (ER) storage diseases: disorders of protein trafficking and the role of ER molecular chaperones. Endocr Rev 19:173-202

49. Brachet V, Pehau-Amaudet G, Desaymard C, Raposo G, Amigorena S 1999 Early endosomes are required for major histocompatiblity complex class II transport to peptide-loading compartments. Mol Biol Cell 10:2891-2904

50. Jin LW, Maezawa I, Vincent I, Bird T 2004 Intracellular accumulation of amyloidogenic fragments of amyloid-beta precursor protein in neurons with Niemann-Pick type $\mathrm{C}$ defects is associated with endosomal abnormalities. Am J Pathol 164:975-985

51. Gustafsson M, Thyberg J, Naslund J, Eliasson E, Johansson J 1999 Amyloid fibril formation by pulmonary surfactant protein C. FEBS Lett 464:138-142

52. Johansson J 2001 Membrane properties and amyloid fibril formation of lung surfactant protein C. Biochem Soc Trans 29:601-606

53. Johansson J, Weaver TE, Tjernberg LO 2004 Proteolytic generation and aggregation of peptides from transmembrane regions: lung surfactant protein $\mathrm{C}$ and amyloid beta-peptide. Cell Mol Life Sci 61:326-335 